\title{
Framing Jawi-Khat Move: A Comparative Analysis of Chinese, English and Malay-language Newspapers in Malaysia
}

\author{
KENNETH LEE TZE WUI \\ WONG WIN WEI \\ Universiti Tunku Abdul Rahman
}

\begin{abstract}
The Malaysian government's move to introduce Jawi-Khat in the Malay-language curriculum in Chinese and Tamil vernacular schools has been fraught with tension and opposition, especially among the Chinese Malaysian community. Being the second-largest ethnic group in Malaysia, the Chinese's negative response to the initiative has generated some implications for the country's socio-political order. Sin Chew Daily, the first newspaper to break the news, was accused by then Finance Minister Lim Guan Eng of stirring fears among the Chinese community. Lim's condemnation of the Chinese daily and the manner in which the whole Jawi-Khat episode played out have raised questions over the roles of Chinese newspapers vis-à-vis their counterparts of other languages in the reportage of the JawiKhat move. Thus, a study on the ways three top vernacular-language newspapers in Malaysia, namely, Sin Chew Daily, The Star and Harian Metro, covered this issue, was conducted. The extent of news coverage, news sources, news frames and valence of the reports were analysed. The research findings reveal that each of the newspapers framed the Jawi-Khat controversy differently. Sin Chew remains a classic ethnic newspaper, having reported extensively on the issue and actively pursued the voice of opposition of various stakeholder groups towards a policy that impacts on Chinese education, a key area vital to the Chinese community. Otherwise, the three newspapers have, to varying degrees, performed the interpretive function within a controlled media landscape and attempted to deescalate conflicts and misunderstanding arising from the Jawi-Khat move.
\end{abstract}

Keywords: Jawi-Khat, media framing, vernacular newspapers, newspaper roles, ethnic relations.

\section{INTRODUCTION}

In July 2019, when Sin Chew Daily, Malaysia's leading Chinese-language daily, broke the news about the Education Ministry's proposal to include several pages of Jawi calligraphy otherwise known as "Khat" - in the Malay Language textbook for Chinese and Tamil vernacular primary schools (Lai, 2019a), it quickly spiraled into a chain of reactions. In fact, Sin Chew headlined the story when even Chinese- and Indian-based components in thenruling Pakatan Harapan (PH) coalition were unaware of it (Lai, 2019a). Other newspapers, especially Chinese dailies, eventually followed suit, making the ethnic-based issue a national agenda for the next few months. Most of the news reports on this issue were fraught with tension and opposition.

The controversial move by the Education Ministry to introduce the Malay-Arabic calligraphy in vernacular school curriculum - hereupon known as the "Jawi-Khat Move" - was met with much contention from various parties. It invited strong opposition not only from the non-Malay grassroots, but also from vocal Chinese educationist and stakeholder groups like Dong Zong and Jiao Zong ("Chinese educationists oppose move", 2019), politicians from both sides of the political divide (Hazlin, 2019; Lai, 2019b; "Plan to introduce Jawi calligraphy", 2019), a coalition of non-governmental organisations (Tawie, 2019) and others due to fear of Islamisation in racially-diverse Malaysia. 
At a time when a number of events were being framed through racial and religious lenses, causing inter-ethnic tensions to be on the rise, objection to the "Jawi-Khat Move" in vernacular schools as expressed largely by the non-Malays in the country quickly drew displeasure from members of the Malay community, who mostly supported the policy. Detractors accused those who objected to the policy as "racist" and "chauvinistic" ("Dong Zong racist", 2019; "Minister: Malays compromised too much", 2019; Syed Jaymal, 2019). An "anti-Jawi-Khat Move" rally also reportedly sparked a nationwide "Buy Muslim First (\#BMF)" movement (Zurairi, 2019). Meanwhile, Lim Guan Eng, the secretary general of the Democratic Action Party (DAP), the latter of which is a component party in the PH coalition often labelled by opponents as a "Chinese chauvinist party" (Kaur, 2017; Mohsin, 2019), condemned Sin Chew for stirring up the Chinese community over the introduction of Jawi-Khat writing in vernacular schools (Prakash, 2019).

In Malaysia, the establishment of vernacular schools has come a long way since the large-scale immigration of the Chinese and Indians during colonial times. These schools, otherwise known as "national-type schools" and which use languages other than Malay and English as the main medium, exist alongside Malay-medium national schools. Though a fixture of the educational landscape in Malaysia, the vernacular schools have often been a subject of contentious debate. The Chinese community and Chinese educationist groups have usually taken a non-compromising stand when it comes to issues relating to Chinese education (Tan \& Teoh, 2015). However, the existence of vernacular schools and the Chinese's insistence over their own mother-tongue education have often been viewed negatively and as a chauvinistic behaviour by the Malays, who form the majority in the country. Right-wing Malay groups and individuals have even filed legal challenges against the constitutionality of the existence of vernacular schools in Malaysia ("Challenge against vernacular schools", 2019; Hidir Reduan, 2020).

Lim's condemnation of Sin Chew and the manner in which the whole Jawi-Khat episode unfolded have inadvertently raised questions over the roles of Chinese newspapers vis-à-vis their counterparts of other languages, in reporting an issue of utmost concern for the ethnic Chinese community in Malaysia. It is understood that newspapers play an important role in framing public opinions. As the Chinese press was actively pursuing the development of the "Jawi-Khat Move", was there any indication that it has framed the issue such that it would raise Chinese ethnic sentiments? Or, were the news articles merely reflecting the Chinese community's perception and response towards the issue? Given this context, this study sets out to examine how a highest-circulated Chinese newspaper in the country would report and frame the controversial "Jawi-Khat Move", which is essentially an ethnic-based issue, in comparison to an English- and a Malay-language mainstream newspaper. Through the analysis of the "Jawi-Khat Move" news coverage, this article is poised to contribute to the literature and knowledge base on newspaper framing.

\section{VERNACULAR NEWSPAPERS IN MALAYSIA AND THEIR SHIFTING ROLES}

In Malaysia, ethnic-based newspapers have proliferated since the pre-independence days. Being largely concerned with the transfer of issues of salience, these ethnic newspapers not only serve to extend and preserve an ethnic's culture, but also act as a symbol of communal identity of the ethnic group. Presently, there are 19 newspapers in Chinese, compared to 16 in English and 13 in Malay in the country (Mohd Izzuddin, 2019). From the country's independence to date, these vernacular-language newspapers have experienced two distinct 
phases of adaptation in order to remain relevant. With various laws, guidelines and regulations in place, the first phase was for these newspapers to attune to the government's effort in nation-building by cutting down on foreign content and by providing more coverage on national news and government's economic policy following Malaya's independence. For instance, with mounting government pressure, Chinese publications began carrying more works by Malaysian authors and featuring more news about other ethnic communities in the country rather than emphasising on content from Mainland China, Taiwan and Hong Kong (Lent, 1974).

The second phase was the newspapers' response to the government's increasing control over press and publications. Over the years, the authorities have sought to employ various laws such as the Printing Presses and Publications Act, Internal Security Act (abolished and replaced by Security Offences [Special Measures] Act 2012) and Sedition Act to censor content and limit critical voices (Ong \& Chibundu, 2018). The major crackdown on the press in 1987 codenamed Operasi Lalang (Weeding Operation) eventually saw tighter legislation on press activities. It has, therefore, been a tough balancing act especially on the part of the vernacular newspapers, for they have to juggle between fulfilling their responsibility as a voice for their respective communities and ensuring what is being reported, will not be construed by the authorities as being inconsistent with government policies or oppositionist in nature. Despite the newspapers' succumbence to government policies and legislative controls over the years, Shaari, Ngu and Raman (2006) argue that the ethnic direction of the vernacular newspapers has not changed much from the colonial days.

\section{OBJECTIVE AND RESEARCH QUESTIONS}

This study aims to examine the coverage of the "Jawi-Khat Move" and matters linked to it in three mainstream vernacular-language newspapers in Malaysia, namely Sin Chew Daily, The Star, and Harian Metro. The research questions ( $R Q$ 's) are as follows:

RQ1. How extensively was the "Jawi-Khat Move" covered by the newspapers?

RQ2. What were the news sources cited by the newspapers in their coverage of the "JawiKhat Move"?

RQ3. What were the news frames reported by the newspapers in their coverage of the "JawiKhat Move"?

RQ4. What was the valence employed by the newspapers in their coverage of the "Jawi-Khat Move"?

\section{THEORETICAL FRAMEWORK}

This study employs framing as a theoretical framework, for it is interested in exploring how the "Jawi-Khat Move" has been framed in the three mentioned vernacular-language newspapers in Malaysia. With its origins in fields like anthropology and sociology, framing has been used as a paradigm to study communication and related behaviour in disciplines such as psychology, speech communication, organisational decision making, economics, health communication, media studies, and political communication (Hallahan, 1999). The theory has also been widely used to study mass media and its effects (Scheufele, 1999).

Entman (1993, p.52) explains, "To frame is to select some aspects of a perceived reality and make them more salient in a communicating text, in such a way as to promote a particular problem definition, causal interpretation, moral evaluation, and/or treatment 
recommendation for the item described." He also posits "frames call attention to some aspects of reality while obscuring others, which might lead to different reactions" (p.55). The media actively set frames of reference that readers or viewers use to interpret and discuss public events (Tuchman, 1978), as well as limit or define the meaning of a story and hence shape people's interpretation of it (Hallahan, 1999).

In the past, various framing studies investigating the newspaper coverage of a slew of issues have been conducted (e.g., An \& Gower, 2009; Yang \& Ahmad Ishak, 2015; Yang \& Rycker, 2017; Ong \& Chibundu, 2018; Victor et al., 2019). Most of these studies examined the extent of news coverage, dominant news sources, news frames and valence of articles of various issues. This study thus adopted the four said aspects related to the framing and reportage of the "Jawi-Khat Move", where their respective operational definitions are given under the subhead "Sampling and coding procedures". Figure 1 demonstrates the research framework.

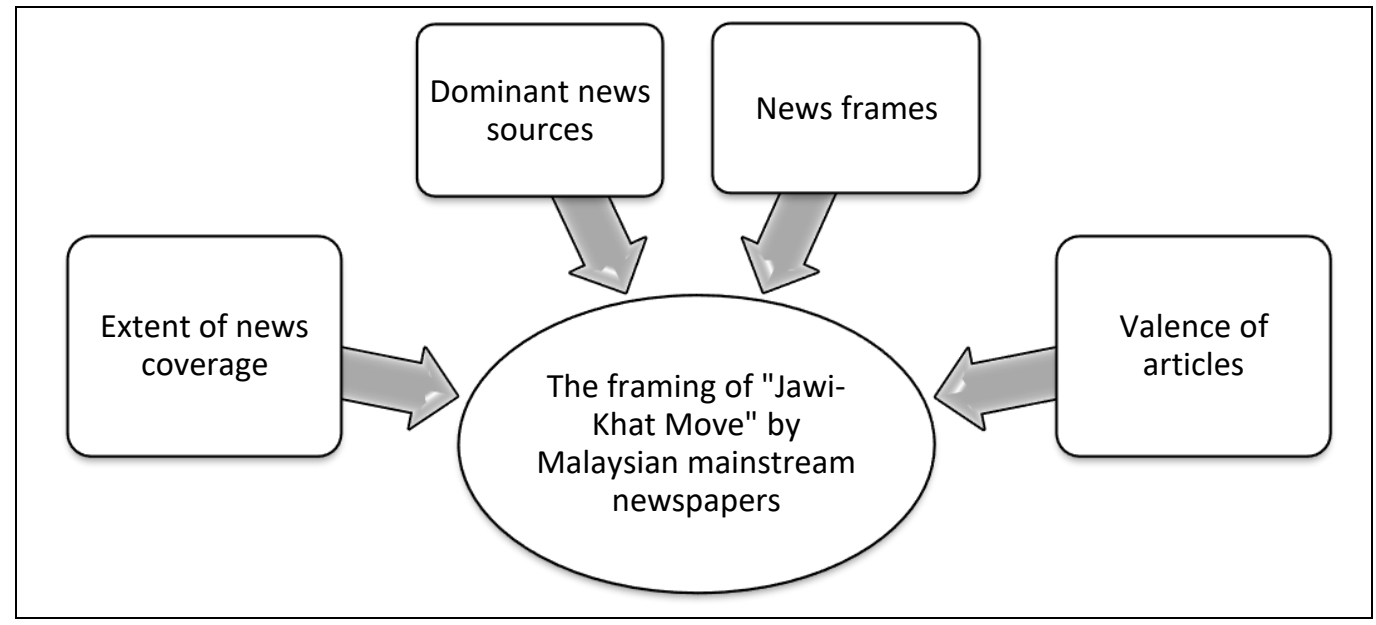

Figure 1: The research framework

\section{METHODOLOGY}

This study would involve a content analysis, defined as "... the systematic, objective, quantitative analysis of message characteristics" (Neuendorf, 2017, p.1). A fast-growing technique in the world of quantitative research, content analysis has been used in various framing studies. In the context of this research, message characteristics that encompass the extent of coverage, dominant news sources, news frames and valence of articles on the "JawiKhat Move" would be content analysed.

\section{Selected Newspapers}

This research involved an analysis of all news articles related to the "Jawi-Khat Move" covered by the mainstream newspapers of three different languages, namely Sin Chew Daily, The Star, and Harian Metro. These vernacular-language newspapers cater to different ethnic groups and have a substantial influence on their readers. Founded in 1929, Sin Chew is the country's leading Chinese newspapers and circulated not only throughout Malaysia, but also in Southern Thailand, Brunei and Indonesia. From July to December 2018, the prominent Chinese daily commanded an average daily print circulation of 277,644 copies (Goh, 2019). In the same period, The Star, which has remained the country's top-circulated English daily for years, recorded 151,623 print copies in circulation and 86,667 copies in its digital replica (Goh, 
2019). Their Malay-language counterpart Harian Metro, a stable owned by Malaysian media conglomerate Media Prima Berhad, saw a daily circulation of 86,000 as of the second half of 2018 (“Utusan Malaysia's closure", 2019). Although no official data on these newspapers' daily circulations is available for 2019 , all three newspapers have been found to be the most frequently-read newspapers and news portals in their respective language categories as of the third quarter of the said year (Vase, 2019). All of them have their online portals where the content is almost identical to their print edition.

\section{Sampling and Coding Procedures}

This study employed the census sample, considered to be the most informative for studies that examine a particular event or series of events (Neuendorf, 2017). The sampling period ran from July 25 to September 25, 2019, the peak period during which the "Jawi-Khat Move" took over the nation by storm. Individual articles consisting of straight news, editorials, and commentaries, among others, published in all sections of the three mainstream newspapers were analysed. Only articles that touched on the implementation of Jawi-Khat and related issues were included for analysis. Articles were identified through rounds of comprehensive database searches; this would involve extraction of the articles from the newspapers' respective online services. Several keywords used in the search included "Khat", "Jawi" and " 爪夷”. Searches using those keywords yielded a total of 426 unique news articles.

Coding was done based on the following dimensions, consistent with the RQ's: 1) extent of news coverage; 2 ) news sources; 3 ) news frames, and 4) valence of articles. The inductive and emergent coding approaches were used for analysing news sources and news frames. The extent of coverage is primarily determined based on the number and types of news articles. After examining all articles, the main news sources cited by the newspapers were pigeonholed accordingly into the following categories:

1) Policymakers, including party leaders from then-ruling Pakatan Harapan (PH) government, as well as state- and federal-level education authority;

2) Opposition leaders, including party leaders from then-opposition bloc such as United Malays National Organisation (UMNO), Malaysian Chinese Association (MCA) and Malaysian People's Movement Party (Gerakan);

3) Non-partisan individuals, including activists, experts, academics, prominent or influential figures, etc;

4) Stakeholder groups, including various unions, associations and non-profit organisations such as educationist groups, parent-teacher associations, as well as parent and resident groups;

5) Police;

6) Opinions - writers who contributed to commentaries, columns, letters to the editors, etc.;

7) Editorials - articles written by the senior editorial staff or publisher of a newspaper representing its views, and

8) Others.

The topics covered in all 426 articles in this study can be categorised into the following news frames, with their respective operational definitions provided: 
1) Responsibility - suggests that some level of the government attempts or has the ability to solve or address any issue that stems from the implementation of Jawi-Khat writing; suggests that some level of the government, an individual or a group is responsible for the issue; suggests the issue requires urgent action by the government.

2) Opposition and criticism - presents people's opposition, criticism, disappointment and skepticism towards the "Jawi-Khat Move".

3) Recommendations - provides suggestions on how the "Jawi-Khat Move" should or could be handled more efficiently.

4) Conflicts and politics - reflects clashes between or among groups, parties or individuals as a result of the Jawi move; one party, individual or group reproaches another; when the Jawi move has been politicised by any one party, yet it does not offer to address the policy in a constructive manner; when any one party takes advantage of the Jawi issue for political gains.

5) Moral and understanding - goes beyond the "Jawi-Khat Move" per se to focus on the moral responsibility to call for a better understanding of and tolerance towards Jawi-Khat, including its origin, history and heritage, with the aim of de-escalating conflicts and misunderstandings; puts any event or issue pertaining to the "Jawi-Khat Move" in the context of moral prescriptions or religious principles.

6) Court and police - covers court cases linked to the "Jawi-Khat Move"; police arrests, police reports, surveillance and investigations; statements made to the police.

7) Others - any other topics that do not fit into the frames above.

Lastly, the valence is also known as the tone or slant of an article. Baumgartner and Wirth (2012) attribute the valence as one of the components responsible for eliciting mood states in the readers by media messages. As mood states have an impact on how readers think and behave, the former may also affect how readers process the information contained in such messages. This study replicated one of the methods of tonality assessment suggested by Michaelson and Griffin (2005), by classifying the tones of news articles into the categories of supportive, critical, and mixed/neutral for the analysis of the stance expressed towards the implementation of the Jawi-Khat writing.

Inter-coder Reliability

An inter-coder reliability test was done for this study. Neuendorf (2017) describes the said test as "... the amount of agreement or correspondence among two or more coders" (p.141), where the reliability sub-sample should be at least $10 \%$ of the full one. An undergraduate student with a background in communication was chosen as the second coder after several rounds of training, with coding instructions and operational definitions provided. The intercoder reliability for this study was done independently by randomly selecting $10 \%$, or 43 articles to be exact from the total pool. The inter-coder reliability of the news types, news sources, news frames, and valence of articles in this study respectively scored over 0.7 , which is generally considered acceptable (e.g., in Baxter, Courage, \& Caine, 2015).

\section{FINDINGS}

This section sets out to highlight some key information based on the four dimensions - the extent of news coverage, news sources, news frames and valence of articles - associated to the framing of the "Jawi-Khat Move" in Sin Chew, The Star and Harian Metro. 
The extent of "Jawi-Khat Move" coverage

Overall, all three vernacular-language newspapers devoted a total of 426 news articles to the issue of the "Jawi-Khat Move". Table 1 shows that straight news was the most frequentlyfeatured type of news, representing $83.8 \%$ of the total coverage on the Jawi-Khat controversy. Opinion pieces, which in the context of this study were largely published in the forms of commentaries and columns by regular writers, came in second at $14.8 \%$. Besides, editorials and features respectively formed just under $1 \%$.

Table 1: "Jawi-Khat Move" coverage and news types

\begin{tabular}{|c|c|c|c|c|c|c|c|c|}
\hline \multirow[b]{2}{*}{ News type } & \multicolumn{2}{|c|}{$\begin{array}{r}\text { Sin Chew } \\
\text { Daily } \\
(n=282)\end{array}$} & \multicolumn{2}{|c|}{$\begin{array}{r}\text { The } \\
\text { Star } \\
(n=112)\end{array}$} & \multicolumn{2}{|c|}{$\begin{array}{l}\text { Harian } \\
\text { Metro } \\
(n=32)\end{array}$} & \multicolumn{2}{|c|}{$\begin{array}{r}\text { All } 3 \\
\text { newspapers } \\
(n=426)\end{array}$} \\
\hline & $\mathrm{n}$ & $\%$ & $\mathrm{n}$ & $\%$ & $\mathrm{n}$ & $\%$ & $\mathrm{n}$ & $\%$ \\
\hline Straight news & 244 & 86.5 & 83 & 74.1 & 29 & 90.6 & 357 & 83.6 \\
\hline Opinions & 35 & 12.4 & 25 & 22.3 & 3 & 9.4 & 63 & 14.8 \\
\hline Editorials & 2 & 0.7 & 2 & 1.8 & 0 & 0.0 & 4 & 0.9 \\
\hline Features & 1 & 0.4 & 2 & 1.8 & 0 & 0.0 & 3 & 0.7 \\
\hline
\end{tabular}

There are, nevertheless, remarkable differences in terms of how each of the three newspapers covered the "Jawi-Khat Move". Sin Chew reported most extensively on the subject - as reflected through a total of its 282 news articles on the issue, in comparison to 112 for The Star and merely 32 for Harian Metro. The leading Chinese daily in Malaysia also devoted the most number of articles to almost all of the news types, including straight news, opinions and editorials. In contrast, its Malay-language counterpart Harian Metro offered the least number of articles for each of such categories.

Editorials - articles are written by the senior editorial staff or publisher of a newspaper oftentimes expressing its view towards an issue - only contributed to $0.9 \%$ of the total coverage across the newspapers. Interestingly, all editorials found in this study came from $\operatorname{Sin}$ Chew and The Sun without Harian Metro's participation. In this case, the two newspapers mostly provided an overall account of how the issue occurred and what various parties thought about it; they also came without an official stance. The same scenario can be observed for feature articles, where Harian Metro dedicated zero space to.

\section{News Sources Employed in "Jawi-Khat Move" Articles}

Table 2 indicates that overall, policymakers from the then-ruling PH coalition made up $30.5 \%$ of the three newspapers' most-cited news sources. Within this category, both state and federal-level leaders from PH component party DAP, as well as the Education Ministry which rolled out the "Jawi-Khat Move", became the dominant sources. Not far behind were stakeholder groups (25.8\%) - who were mostly critical of the "Jawi-Khat Move" - as well as leaders from then then-opposition parties (16.7\%), including UMNO, MCA and Gerakan. It is worth noting that non-partisan individuals such as activists, experts, academics, as well as prominent and influential figures, too, were given considerable attention (7\%). The police were among the least employed sources, but this was because there were only a few cases linked to the force. 
Framing Jawi-Khat Move: A Comparative Analysis of Chinese, English and Malay-language Newspapers in

Table 2: News sources cited in "Jawi-Khat Move" articles

\begin{tabular}{lrrrrrrrr}
\hline & $\begin{array}{r}\text { Sin Chew } \\
\text { Daily } \\
\text { (n=282) }\end{array}$ & & $\begin{array}{r}\text { The } \\
\text { Star } \\
\text { (n=112) }\end{array}$ & $\begin{array}{r}\text { Harian } \\
\text { Metro } \\
\text { (n=32) }\end{array}$ & $\begin{array}{r}\text { All 3 } \\
\text { News source }\end{array}$ \\
\cline { 2 - 9 } & $\mathrm{n}$ & $\%$ & $\mathrm{n}$ & $\%$ & $\mathrm{n}$ & $\begin{array}{r}\text { \% } \\
\text { (n=426) }\end{array}$ \\
Policymakers & 77 & 27.3 & 39 & 34.8 & 14 & 43.8 & 130 & 30.5 \\
Stakeholder groups & 97 & 34.4 & 9 & 8.0 & 4 & 12.5 & 110 & 25.8 \\
Opposition leaders & 51 & 18.1 & 20 & 17.9 & 0 & 0.0 & 71 & 16.7 \\
Opinions & 35 & 12.4 & 22 & 19.6 & 3 & 9.4 & 60 & 14.1 \\
Non-partisan individuals & 13 & 4.6 & 12 & 10.7 & 5 & 15.6 & 30 & 7.0 \\
Police & 3 & 1.1 & 7 & 6.3 & 6 & 18.8 & 16 & 3.8 \\
Editorials & 2 & 0.7 & 2 & 1.8 & 0 & 0.0 & 4 & 0.9 \\
Others & 4 & 1.4 & 1 & 0.9 & 0 & 0.0 & 5 & 1.2 \\
\hline
\end{tabular}

Individually, Sin Chew covered stakeholder groups (34.4\%) most frequently compared to policymakers $(27.3 \%)$ and opposition leaders (18.1\%). As for The Star, policymakers became the most employed news source, representing $34.8 \%$ of the paper's overall article. Unlike in Sin Chew, however, stakeholder groups were not among the English daily's top three sources. While Harian Metro's coverage on the Jawi-Khat issue was relatively scarce, it cited policymakers the most (43.8\%), followed by police $(18.8 \%)$ and non-partisan individuals (15.6\%).

\section{News Topics Linked to "Jawi-Khat Move" Coverage}

The reportage on the "Jawi-Khat Move" involved various topics otherwise known as "news frames" in this study. Although the "opposition and criticism" frame is ranked first overall, as can be seen in Table 3, the frame was, however, not the most salient one in The Star and Harian Metro. Sin Chew actively pursued the opposition, criticism, disappointment and skepticism towards the "Jawi-Khat Move" as expressed by various groups, parties or individuals, whether they were from the political arena or otherwise (e.g., in "MCA Youth Selangor collects signature", 2019; "Perak Chinese groups to launch signature drive", 2019; "Sabah PKR: Khat should not be made mandatory", 2019).

Table 3: News frames employed in "Jawi-Khat Move" articles

\begin{tabular}{|c|c|c|c|c|c|c|c|c|}
\hline \multirow[b]{2}{*}{ News frame } & \multicolumn{2}{|c|}{$\begin{array}{r}\text { Sin Chew } \\
\text { Daily } \\
(n=282)\end{array}$} & \multicolumn{2}{|c|}{$\begin{array}{r}\text { The } \\
\text { Star } \\
(n=112)\end{array}$} & \multicolumn{2}{|c|}{$\begin{array}{c}\text { Harian } \\
\text { Metro } \\
(n=32)\end{array}$} & \multicolumn{2}{|c|}{$\begin{array}{r}\text { All } 3 \\
\text { newspapers } \\
(n=426)\end{array}$} \\
\hline & $\mathrm{n}$ & $\%$ & $\mathrm{n}$ & $\%$ & $\mathrm{n}$ & $\%$ & $\mathrm{n}$ & $\%$ \\
\hline Opposition and criticism & 110 & 39.0 & 10 & 8.9 & 1 & 3.1 & 121 & 28.4 \\
\hline Responsibility & 78 & 27.7 & 25 & 22.3 & 4 & 12.5 & 107 & 25.1 \\
\hline Moral and understanding & 49 & 17.4 & 26 & 23.2 & 14 & 43.8 & 89 & 20.9 \\
\hline Conflicts and politics & 20 & 7.1 & 37 & 33.0 & 5 & 15.6 & 62 & 14.6 \\
\hline Court and police & 11 & 3.9 & 8 & 7.1 & 8 & 25.0 & 27 & 6.3 \\
\hline Recommendations & 6 & 2.1 & 6 & 5.4 & 0 & 0.0 & 12 & 2.8 \\
\hline Others & 8 & 2.8 & 0 & 0.0 & 0 & 0.0 & 8 & 1.9 \\
\hline
\end{tabular}

The Star is observed to have played up conflicts and politics linked to the "Jawi-Khat Move" the most, as exemplified in one-third of the English paper's total articles. An example of such articles is given in Zakiah and Carvalho (2019), which reported Bersatu Youth's attempt to launch an online petition to ban Dong Zong following the Chinese educationist group's call to stop the "Jawi-Khat Move". Another example is the story of an angry man who 
pelted a DAP service centre with eggs over the "Jawi-Khat Move" ("Man throws eggs", 2019). Meanwhile, Harian Metro mostly focused on the "moral and understanding" frame, as can be observed in Zuhainy (2019) where it featured an interview with an Islamic Studies teacher who related his experience in teaching Jawi calligraphy to students of various races. Recommendations or suggestions on how the "Jawi-Khat Move" could have been implemented better were a little underreported across all three newspapers.

\section{The Valence of "Jawi-Khat Move" Articles}

The valence or slant of an article was measured based on the stance the dominant news source or sources in the said article expressed towards the "Jawi-Khat Move". Table 4 shows that overall, the policy has not been too well-received. The reportage in Sin Chew was generally not in favour of the move, as given by $58.5 \%$ of its total coverage that was critical of it. Articles with a neutral stance or mixed reactions, and also ones with a supportive stance towards the policy, were rather balanced. However, this was played out differently in The Star, where most articles expressed a neutral or mixed stance (46.4\%). Only $16.1 \%$ of the coverage in the most-read English tabloid had a supportive valence. As for Harian Metro, articles with a neutral or mixed stance were published as much as those with a supportive stance. Only a handful did not put the policy in the positive light.

\begin{tabular}{|c|c|c|c|c|c|c|c|c|}
\hline \multirow[b]{2}{*}{ Valence } & \multicolumn{2}{|c|}{$\begin{array}{r}\begin{array}{r}\text { Sin Chew } \\
\text { Daily } \\
(n=282)\end{array}\end{array}$} & \multicolumn{2}{|c|}{$\begin{array}{r}\text { The } \\
\text { Star } \\
(\mathrm{n}=112)\end{array}$} & \multicolumn{2}{|c|}{$\begin{array}{c}\text { Harian } \\
\text { Metro } \\
(n=32)\end{array}$} & \multicolumn{2}{|c|}{$\begin{array}{r}\text { All } 3 \\
\text { newspapers } \\
(n=426)\end{array}$} \\
\hline & $\mathrm{n}$ & $\%$ & $\mathrm{n}$ & $\%$ & $\mathrm{n}$ & $\%$ & $\mathrm{n}$ & $\%$ \\
\hline Critical & 165 & 58.5 & 42 & 37.5 & 6 & 18.8 & 213 & 50.0 \\
\hline Neutral/Mixed & 58 & 20.6 & 52 & 46.4 & 13 & 40.6 & 123 & 28.9 \\
\hline Supportive & 59 & 20.9 & 18 & 16.1 & 13 & 40.6 & 90 & 21.1 \\
\hline
\end{tabular}

\section{DISCUSSION}

Based on the findings above, the indications are clear that each of the three mainstream newspapers has had a different focus when presenting the whole "Jawi-Khat Move" to its readers. The following are some facts to support the observation:

\section{Sin Chew Daily - A Classic Ethnic Newspaper}

Of the three newspapers, Sin Chew is seen as a pioneer and has been noticeably the most vigorous in pursuing matters and the controversy surrounding the "Jawi-Khat Move". After it became the first newspaper in the country to have broken the news on the "Jawi-Khat Move", other newspapers immediately followed suit, thereupon exemplifying the power of the mass media. With the issue being assiduously pursued, it subsequently prompted stakeholders to push their voice of opposition out, as well as forced the policymakers to come out to clarify and address the controversy. To put things into perspective, Sin Chew ran over two-half times as much news on the issue compared to The Star, and close to nine times more than Harian Metro.

Besides, the highest-circulated Chinese daily was also the most aggressive in reporting the sentiments of various stakeholder groups, including unions, associations, and nongovernmental organisations - the majority of which were Chinese-based, towards a policy that impacts on Chinese education, one of the key areas vital to the Chinese Malaysian 
community. Based on the research data not included in the tables above, although $80 \%$ of $\operatorname{Sin}$ Chew's articles citing stakeholder groups were critical of the policy, the representation of such groups have been rather diverse and wide-ranging, going from the prominent Chinese educationist groups under the collective name of "Dong Jiao Zong" to various associations, such as a number of parent-teacher associations, The Association of Graduate Universities and Colleges in China, Malaysia, and the Peninsular Malay Students Union. It must, however, be noted that despite Sin Chew's focus on these stakeholder groups, the news frames or topics linked to them were varied and not only confined to the negative sentiments resulting from the opposition, criticism, disappointment and skepticism they demonstrated towards the "Jawi-Khat Move".

Given that the Chinese newspapers have traditionally demonstrated the tendency to focus on events important to the Chinese community (Lent, 1974; Mohd Dhari, 1992; Shaari et al., 2006), it is not unusual for an influential ethnic newspaper like Sin Chew with a rich history dated to as early as 1929 in the pre-independence Malaya, to serve as a "voice" for the Chinese Malaysians. In this issue, Sin Chew's active pursuance of the voices of various stakeholder groups' representing the grassroots Chinese also coincided with the fact that the Chinese community takes to heart matters pertaining to Chinese education. Many from the stakeholder groups feared that the introduction of Jawi-Khat lessons in vernacular schools would further erode Chinese education in the context of multicultural Malaysia. Postindependence Malaysia saw Chinese educational rights and interests, among others, being increasingly eroded in the government's pursuit of nation-building that emphasises on a Bumiputera-centered identity and the Malay culture (Loh, 2002). The development of Chinese education, thus, is a result of a continuous social movement that has depended mainly on the strength of the Chinese community and its self-reliance to keep it going (Xia, Yang, \& Lee, 2018). Therefore, it is understandable that Sin Chew, whose priority is reporting issues pertaining to Chinese education and culture ( $\mathrm{Ng} \&$ Lee, 2018), would actively report on the sentiments of the community about the "Jawi-Khat Move".

\section{Performing The Interpretive Function within a Controlled Media Landscape}

If the news types were to be re-organised into fact-based (straight-news, features) versus opinion-based (opinions, editorials) articles, the results are clear-cut, that Harian Metro commanded the lowest percentage of opinion-based articles. Although Sin Chew published more opinion-based and oftentimes interpretive articles compared to The Star, the latter had the highest percentage of such pieces. While a majority of the opinion pieces in The Star and Sin Chew expressed a stance towards the initiative to introduce Jawi-Khat in vernacular schools, many of them also provided interpretations of and meanings (or the lack thereof) to the issue. The major difference between the three publications was that opinion-based pieces in Sin Chew were mostly critical of the "Jawi-Khat Move", whereas the ones in The Star were mostly neutral. In contrast, almost all such articles were supportive of the government move in Harian Metro. Regardless of what stance the articles were trying to express, through the timely transfer of interpretive cues, all three newspapers attempted to mobilise the public members to understand and respond to the issue in particular manners, as consistent with the Framing Theory.

Nevertheless, in presenting the "Jawi-Khat Move", fact-based reporting took a strong lead over opinion journalism. Straight news, otherwise known as "spot" or "hard" news and usually taking on a factual approach, effortlessly accounted for slightly over $80 \%$ of the total 
coverage across all three newspapers (see Table 1). This stood in stark contrast to the more opinionated content. However, such a composition in the news coverage is expected of Malaysian newspapers, as similar studies into other political issues in the country also revealed a similar pattern (e.g., Ahmad Ishak \& Yang, 2013; Yang \& Rycker, 2017; Ong \& Chibundu, 2018; Victor et al., 2019). Although Malaysia's media freedom had improved under the PH administration ("Better media freedom", 2019), the mainstream media landscape generally remains tightly controlled. Where the media is mostly private but subject to various legislative mechanisms and ownership structures through which compliance is ensured (Abbott, 2011), perhaps sticking to fact-based reporting rather than opinion pieces not only serves as a safe way of ensuring the bottom line of the media laws and regulations is not compromised, but also helps reinforce traditional journalistic norms and authoritativeness in an era where citizens call themselves "journalists".

\section{De-escalating Conflicts and Misunderstanding}

News sources are said to be the "frame sponsors" for news articles (Tankard, 2008). Given that policymakers, stakeholder groups and opposition leaders were overall the dominant news sources in this study, it only makes sense that "opposition and criticism" made the top frame. While a substantial number of the articles citing the policymakers reported on the government's attempt to address and improve the Jawi-Khat policy, not all from the policymaker group were supportive of the "Jawi-Khat Move". From within this group, while the Education Ministry was evidently supportive of the move, DAP leaders were divided over it (e.g., "DAP branches form a coalition", 2019; "DAP Youth against Khat move", 2019). This was reflected through the critical stance expressed towards the move by a number of unhappy leaders from the Chinese-based party. Besides, opposition towards the move from various stakeholder groups and opposition leaders - the latter of which was largely made up of those from the MCA and Gerakan - would also give a majority of the total coverage the "opposition and criticism" spin. This was especially evident in Sin Chew, which was mostly responsible for publishing the highest number of such articles and thus bringing up the total percentage of articles containing the said frame.

As politicians from both sides of the political divide and the grassroots groups were divided over the "Jawi-Khat Move", it is perhaps encouraging to see that all three newspapers devoted some $20 \%$ of the total coverage to the "moral and understanding" frame (see Table 3). Although Harian Metro took a lead in this percentage-wise by publishing $43.8 \%$ of such articles, it is only fair to acknowledge that Sin Chew and The Star, too, were attempting to narrow the gap in this racially-sensitive issue that requires understanding beyond the JawiKhat policy. Under this frame, by quoting or interviewing various groups, parties or individuals, the articles tried to promote an informed understanding of and tolerance towards Jawi-Khat through the sharing of its history, as well as through the assurance that learning the Jawi script would not make one Malay or Muslim. In this frame, the relevant articles did not focus on the issue of the "Jawi-Khat Move" per se, but instead went beyond it to educate readers on the origin, history and heritage of the Jawi script with the aim of de-escalating conflicts and misunderstandings. In that regard, Junne (2013) asserts that while the media plays a crucial role in conflict escalation, it also has the potential to tame conflicts by offering options for resolution. Such an approach, known as "peace journalism", has the potential to transform conflicts to a resolution where it allows journalists "... to view, interpret, source and narrate conflicts in ways that seek non-violent responses in society..." (Aslam, 2014, p.2). 
Similar to the concepts of framing and agenda-setting, such journalism is when the media chooses what to report and how to report it, except that it creates opportunities for the public to consider and value peaceful responses to conflicts. Having said that, it would also be helpful if the newspapers could publish more stories on the "recommendations" angle that was a little underreported in this study.

\section{Jawi-Khat Move - Yet Another Racially-Divided Issue}

Although the "Jawi-Khat Move" is an issue directly affecting the non-Malays, from the research data, it is obvious that essentially those supporting and opposing it have been markedly divided along ethnic and religious lines. This is unsurprising, considering that racially-charged rhetoric has dominated the political scene of multi-ethnic and multi-religious Malaysia since its independence (Sukumaran, 2018). Generally, the policy has been both wellreceived and defended by the Malay-Muslims. In the case of this study, most Malay-Muslims were of the opinion that the implementation was sensible and that Jawi should be deemed an integral part of the national heritage considering the Malay language was traditionally written in the Jawi script. On top of that, Malay nationalist leaders in the political arena such as Abdul Hadi Awang and Ismail Sabri Yaakob, often seen to bank on the support of fellow Malay-Muslims, would take this opportunity to be especially vocal in condemning and demonising those who opposed the move (e.g., "Hadi hits out at 'Islamaphobic' resistance to Jawi", 2019; "Ismail Sabri hits out at DAP, Dong Zong", 2019).

On the other hand, among the Chinese and Indians, this policy stirred fears of Arabianisation and Islamisation. Those who voiced their opposition, skepticism and dissatisfaction towards the "Jawi-Khat Move" not only included a few DAP leaders and a slew of worried Chinese and Tamil stakeholder groups, but also leaders from MCA and Gerakan, both of which are Chinese-based political parties linked to then-overthrown Barisan Nasional (BN) government in the 2018 general election. Such opposition, especially among the Chinese from both sides of the political divide, bears a striking resemblance to the incident in 1987 when Datuk Seri Anwar Ibrahim, then Education Minister under BN, approved a plan to send non-Chinese speaking senior assistants and principals to vernacular Chinese primary schools (Wong, 2017; Ang, 2009; Lai, 2019a). This caused Dong Jiao Zong to mobilise a demonstration, where "... for the first time in the history of Malaysia, Chinese were united despite geographical location, social or economy class, as well as political stands" (Sia, as cited in Ang, 2009, p.18).

\section{CONCLUSION}

As the newspapers were actively pursuing the "Jawi-Khat Move" agenda and transferring salient cues to the readers, thereby making it an important public agenda, it is important to note that at the same time, politicians, grassroots groups and other stakeholders in this controversy were not without their own agenda in influencing public policy. The former scenario is popularly known as "agenda-setting" while the latter refers to "agenda building". Hence, the authors believe that while each newspaper was trying to frame the issue in a particular way, both agenda-setting and agenda building were, too, taking shape. Nevertheless, over the span of two months during the peak of the issue, the newspapers' active following up on and monitoring of the "Jawi-Khat Move" served as a good example of the media performing the surveillance or information function of mass communication as put forth by theorists Harold D. Lasswell and Charles R. Wright in 1948 and 1960 respectively. In 
this controversy, not only were the newspapers keeping their readers informed of the factual $5 \mathrm{~W}$ 's and $1 \mathrm{H}$ of the issue, Sin Chew and The Star, especially, also helped them analyse what was to be expected of the issue, and a portion of such analysis was provided through opinionbased articles. The interpretations that came with these opinion pieces served to fulfil the correlation function of mass communication closely linked to the aforementioned surveillance or information function. The correlation function deals with the way the newspapers selected and interpreted information on the "Jawi-Khat Move", thereby providing an avenue of discourse on the issue.

From this study, it can be observed that although the roles of newspapers in the country have shifted significantly especially after independence, Sin Chew's ethnic direction and commitment to the coverage of issues and discourses vital to the Chinese community remains strong. While it does not occur to the authors that Sin Chew was deliberately trying to stroke Chinese fears or sentiments through its extensive coverage on the controversial "Jawi-Khat Move", it tried to frame it as an important one that required urgent attention from the ethnic community. Meanwhile, where the English press in the pre-independence days "... promoted its image as the defender of the interest of the immigrants in light of the growing forces of Malays nationalism as championed by the Malay press..." (Mohd Dhari, 1992, p.127), The Star, in reporting the "Jawi-Khat Move", took the middle ground by focusing more on the policymakers and less on the opposition and criticism demonstrated by various groups, parties or individuals towards the issue. This is probably due to the daily's more diverse readers comprising of different races, including the English-literate Malays. Comparatively, Harian Metro seemed less enthusiastic about making the issue salient but was nevertheless inclined to portray the "Jawi-Khat Move" in a positive light.

\section{BIODATA}

Kenneth Lee Tze Wui is a lecturer at the Faculty of Creative Industries, Universiti Tunku Abdul Rahman, Malaysia. His research interests are media, ethnicity and nation-building. Email: leetw@utar.edu.my

Wong Win Wei is a graduate of the Faculty of Creative Industries, Universiti Tunku Abdul Rahman, Malaysia. She is passionate about media and psychology. Email: wongwinwei@1utar.my 


\section{REFERENCES}

Abbott, J. P. (2011). Electoral authoritarianism and the print media in Malaysia: Measuring political bias and analyzing its cause. Asian Affairs: An American Review, 38(1), 1-38. https://www.doi.org/10.1080/00927678.2010.520575

Ahmad Ishak, M. S., \& Yang, L. F. (2013). Covering Batu Sapi by-election: Analysis of Sin Chew Daily and Nanyang Siang. Malaysian Journal of Democracy and Election Studies, 1(1), 116-131.

An, S.-K., \& Gower, K. K. (2009). How do the news media frame crises? A content analysis of crisis news coverage. Public Relations Review, 35(2), 107-112. https://www.doi.org/10.1016/j.pubrev.2009.01.010

Ang, M. C. (2009). The Chinese education movement in Malaysia. Southern Papers Series. Working Papers No.2. Argentina: Consejo Lationamericano de Ciencias Sociales.

Aslam, R. (2014). The role of media in conflict: Integrating peace journalism in the journalism curriculum (Unpublished doctoral dissertation, Auckland University of Technology, Auckland, New Zealand).

Baumgartner, S. E., \& Wirth, W. (2012). Affective priming during the processing of news articles. Media Psychology, 15(1), 1-18. https://www.doi.org/10.1080/15213269.2011.648535

Baxter, K., Courage, C., \& Caine, K. (2015). Understanding your users: A practical guide to user research methods, tools, and techniques. San Francisco: Elsevier Science \& Technology.

Better media freedom after GE14, hard work remains to improve further: Analysts. (2019, May 13). The Sun Daily. Retrieved from https://www.thesundaily.my/local/bettermedia-freedom-after-ge14-hard-work-remains-to-improve-further-analystsLJ865793

Challenge against vernacular schools refiled in High Court. (2019, December 17). Free Malaysia Today. Retrieved from https://www.freemalaysiatoday.com/category/nation/2019/12/17/challengeagainst-vernacular-schools-refiled-in-high-court/

Chinese educationists oppose move to introduce 'khat' writing for BM syllabus. (2019, July 31). Free Malaysia Today. Retrieved from https://www.freemalaysiatoday.com/category/nation/2019/07/31/chineseeducationists-oppose-move-to-introduce-khat-writing-for-bm-syllabus

DAP branches form coalition to oppose Jawi in school. (2019, August 3). The Star. Retrieved from https://www.thestar.com.my/news/nation/2019/08/03/dap-branches-formcoalition-to-oppose-jawi-in-school

Dong Zong racist, says Dr M on objection over khat. (2019, August 12). Free Malaysia Today. Retrieved from https://www.freemalaysiatoday.com/category/nation/2019/08/12/dong-zongracist-says-dr-m-on-objection-over-khat

Entman, R. M. (1993). Framing: Toward clarification of a fractured paradigm. Journal of Communication, 43(4), 51-58. https://www.doi.org/10.1111/j.14602466.1993.tb01304.x

Goh, J. (2019, September 18). ABC's future hazy as major publishers plan to pull out. The Edge Markets. Retrieved from https://www.theedgemarkets.com/article/abcs-futurehazy-major-publishers-plan-pull-out 
Hidir Reduan Abdul Rashid. (2020, March 23). Isma files legal challenge over validity of vernacular schools. Malaysiakini. Retrieved from https://www.malaysiakini.com/news/516188

Hallahan, K. (1999). Seven models of framing: Implications for public relations. Journal of Public Relations Research, 11(3), 205-242. https://www.doi.org/10.1207/s1532754xjprr1103_02

Hazlin Hassan. (2019, August 5). Move to introduce Arabic script in Malaysian schools upsets non-Malay groups. The Straits Times. Retrieved from https://www.straitstimes.com/asia/se-asia/move-to-introduce-arabic-script-inmalaysian-schools-upsets-non-malay-groups

Junne, G. (2013, September). The role of media in conflict transformation. Retrieved from http://www.irenees.net/bdf_fiche-analyse-1002_en.html

Kaur, M. (2017, September 30). Mahathir: I now realise DAP is not chauvinist at all. Free Malaysia Today. Retrieved from https://www.freemalaysiatoday.com/category/nation/2017/09/30/mahathir-i-nowrealise-dap-is-not-chauvinist-at-all

Lai, A. (2019a, August 18). Khat controversy underscores mistrust. The Star. Retrieved from https://www.thestar.com.my/news/nation/2019/08/18/khat-controversyunderscores-mistrust

Lai, A. (2019b, August 8). Dr Mah defends Chinese community's stance on khat in schools. The Star. Retrieved from https://www.thestar.com.my/news/nation/2019/08/08/drmah-defends-chinese-community039s-stance-on-khat-in-schools

Lent, J. A. (1974). Malaysian Chinese and their mass media: History and survey. Asian Profile, 2(4), 1-19.

Loh, F. K. W. (2002). Developmentalism and the limits of democratic discourse. In Loh, F. K. W., \& Khoo, B. T. (Eds.), Democracy in Malaysia: Discourses and practices. (pp. 19-50). Richmond, Surrey: Curzon Press.

Michaelson, D., \& Griffin, T. L. (2005). A new model for media content analysis. Retrieved from Institute for Public Relations website: https://instituteforpr.org/wpcontent/uploads/MediaContentAnalysis.pdf

Minister: Malays compromised too much with 'racists', time to rise up. (2019, August 14). Malaysiakini. Retrieved from https://www.malaysiakini.com/news/487876

Mohd Dhari Othman. (1992). Malaysian press: A brief account of newspapers published in British Malaya. Jurnal Komunikasi: Malaysian Journal of Communication, 8, 117-130.

Mohd Izzuddin Ramli. (2019). Breaking old habits is vital for Malaysia's mainstream newspapers. Penang Institute. Retrieved from https://penanginstitute.org/wpcontent/uploads/2019/04/apr_12_2019_din_download.pdf

Mohsin Abdullah. (2019, February 7). DAP and the Malays. The Edge Markets. Retrieved from https://www.theedgemarkets.com/article/dap-and-malays

Neuendorf, K. A. (2017). The content analysis guidebook (2nd Ed.). Thousand Oaks, UK: Sage.

$\mathrm{Ng}$, M. L., \& Lee, Y. B. (2018). Malaysian Chinese language newspapers and national identity: A study of the roles of Sin Chew Daily in Chinese cultural preservation and nation building. Kajian Malaysia, 36(1), 63-103. https://www.doi.org/10.21315/km2018.36.1.4 
Ong, S. W., \& Chibundu, I. S. (2018). Debating vernacular school system in Malaysia: A comparative analysis of multi-lingual local newspapers. SEARCH: The Journal of the South East Asia Research Centre for Communication and Humanities, 10(2), 87-114.

Plan to introduce Jawi calligraphy in schools 'totally flies in the face' of consensus. (2019, July 30). DayakDaily. Retrieved from https://dayakdaily.com/plan-to-introduce-jawicalligraphy-in-schools-totally-flies-in-the-face-of-consensus

Prakash, G. (2019, August 6). Guan Eng: Non-Malay community alarmed by Chinese daily's report on khat controversy. Malay Mail. Retrieved from https://www.malaymail.com/news/malaysia/2019/08/06/guan-eng-non-malaycommunity-alarmed-by-chinese-dailys-report-on-khat-contr/1777930

Scheufele, D. A. (1999). Framing as a theory of media effects. Journal of Communication, 49(1), 103-122. https://www.doi.org/10.1111/j.1460-2466.1999.tb02784.x

Shaari, H., Ngu, T. H., \& Raman, V. (2006). Covering race and religion: The Moorthy and Nyonya Tahir cases in four Malaysian newspapers. Kajian Malaysia, 14(1\&2), 185-201.

Sukumaran, T. (2018, July 20). Religion, race, politics: What's causing Malaysia's divide? South China Morning Post. Retrieved from https://www.scmp.com/weekasia/society/article/2108367/religion-race-politics-whats-causing-malaysias-greatdivide

Syed Jaymal Zahid. (2019, August 4). Learning Jawi didn't make me less Chinese but more Malaysian, says Kit Siang. Malay Mail. Retrieved from https://www.malaymail.com/news/malaysia/2019/08/04/learning-jawi-didnt-makeme-less-chinese-but-more-malaysian-says-kit-siang/1777477

Tan, Y. S., \& Teoh H. S. (2015). The development of Chinese education in Malaysia, 19521975: Political collaboration between the Malaysian Chinese Association and the Chinese educationists. History of Education, 44(1), 83-100, https://www.doi.org/10.1080/0046760X.2014.959073

Tankard, Jr., J. W. (2008). The empirical approach to the study of media framing. In Reese, S. D., Gandy, O. H., \& Grant, A. E. (Eds.), Framing public life: Perspectives on media and our understanding of the social world (pp. 95-105). New Jersey: Lawrence Erlbaum Associates.

Tawie, S. (2019, September 23). Coalition of NGOs urge Sarawak govt to make a stand on khat issue. Malay Mail. Retrieved from https://www.malaymail.com/news/malaysia/2019/09/23/coalition-of-ngos-urgesarawak-govt-to-make-a-stand-on-khat-issue/1793508

Tuchman, G. (1978). Making news a study in the construction of reality. New York: Free Press. Utusan Malaysia's closure may benefit Media Prima. (2019, October 10). The Borneo Post. Retrieved from https://www.theborneopost.com/2019/10/11/utusan-malaysiasclosure-may-benefit-media-prima/

Vase. (2019). Malaysia's 2019 media consumption report. Retrieved from https://vase.ai/resources/malaysias-media-consumption-2019/

Victor, J., Heng, J. G. K., Govindaraju, G. M., Ling, T. P., Rajaratnam, U. D., \& Fong, Y. L. (2019). Media reporting of suicide: A comparative framing analysis of Malaysian newspapers. SEARCH Journal of Media and Communication Research, 11(2), 73-88.

Wong, C. W. (2017, October 29). Ops Lalang, our dark days. The Star. Retrieved from https://www.thestar.com.my/opinion/columnists/on-the-beat/2017/10/29/opslalang-our-dark-days 
Xia, N., Yang, Y., \& Lee, Y. F. (2018). Chinese education in Malaysia under Malaysian ethnic politics. Journal of Politics and Law, 11(2), 23-36. https://www.doi.org/10.5539/jpl.v11n2p23

Yang, L. F., \& Ahmad Ishak, M. S. (2015). Framing inter-religious dispute: A comparative analysis of Chinese-, English-, and Malay-language newspapers in Peninsular Malaysia. Chinese Journal of Communication, 9(2), 103-123. https://www.doi.org/10.1080/17544750.2015.1096802

Yang, L. F., \& Rycker, A. D. (2017). From theft to racist brawl: The framing of Low Yat incident by Malaysian newspapers. Asian Journal of Communication, 27(6), 631-647. https://www.doi.org/10.1080/01292986.2017.1294191

Zakiah Koya, \& Carvalho, M. (2019, August 13). Bersatu youth launches online petition to ban Dong Zong. The Star. Retrieved from https://www.thestar.com.my/news/nation/2019/08/13/bersatu-youth-launchesonline-petition-to-ban-dong-zong

Zuhainy Zulkiffli. (2019, August 7). Indahnya seni khat [Beautiful is Khat]. Harian Metro. Retrieved from https://www.hmetro.com.my/mutakhir/2019/08/483542/indahnyaseni-khat

Zurairi AR. (2019, September 5). Here's how an anti-khat rally in Jerantut sparked a nationwide 'buy Muslim first' wave. Malay Mail. Retrieved from https://www.malaymail.com/news/malaysia/2019/09/05/heres-how-an-anti-khatrally-in-jerantut-sparked-a-nationwide-buy-muslim-fi/1787377

反对爪夷文纳入华淡小. 马青12区团收集700签名 [MCA Youth Selangor collects signatures to oppose move to introduce Khat]. (2019, September 1). Sin Chew Daily. Retrieved from https://www.sinchew.com.my/content/content_2109346.html

反爪夷文书法.沙比利：放肆、没教养、挑战马来人耐心 [Ismail Sabri hits out at DAP, Dong Zong over resistance to Jawi]. (2019, August 6). Sin Chew Daily. Retrieved from https://www.sinchew.com.my/content/content_2095748.html

反爪夷文纳华小课程 霹董联会等28日邀签名 [Perak Chinese groups to launch signature drive to appeal against Khat move]. (2019, August 26). Sin Chew Daily. Retrieved from https://www.sinchew.com.my/content/content_2106139.html

哈迪：反对者是英殖民者后代. "爪夷文敌人是伊党敌人" [Hadi hits out at 'Islamophobic' resistance to Jawi]. (2019, August 6). Sin Chew Daily. Retrieved from https://www.sinchew.com.my/content/content_2095924.html

沙巴公正党：爪夷文书法艺术 不应强制性推行 [Sabah PKR: Khat should not be made mandatory]. (2019, August 5). Sin Chew Daily. Retrieved from https://www.sinchew.com.my/content/content_2095204.html

疑因网传爪夷文立场名单. 华男直播蛋洗火箭服务中心 [Man throws eggs at DAP office in protest of Jawi policy]. (2019, August 4). Sin Chew Daily. Retrieved from https://www.sinchew.com.my/content/content_2095057.html

社青团反对爪夷文书法课.联署支部增至212 [DAP Youth against Khat move]. (2019, August 3). Sin Chew Daily. Retrieved from https://www.sinchew.com.my/content/content_2094273.html 